\title{
Nutritional factors in milk from Brazilian mothers delivering small for gestational age neonates *
}

\author{
Anete S.Grumach"*, Solange E.I.Jerônimo**, Marcia Hage**, Magda M.S.Carneiro-Sampaio**
}

\begin{abstract}
GRUMACH, A.S. et al. Nutritional factors in milk from Brazilian mothers delivering small for gestacional age neonates. Rev. Saúde Pública, 27: 455-62, 1993. The composition of breast milk from brazilian mothers delivering low birthweight infants and its adequacy as a source of nutrients for this group has not yet been fully elucidated. A total of 209 milk samples from 66 women were analysed. The mothers were divided into three groups: $\mathrm{Gl}$, mothers delivering term babies of low birthweight (TSGA, $n=16$ ); G2, mothers delivering preterm babies of appropriate birthweight (PTAGA, n=20); G3, mothers delivering term babies of appropriate birthweight (TAGA, $n=30$ ). The following factors were analysed: osmolarity, total proteins and protein fractions, creamatocrit, sodium, potassium, calcium and magnesium. Milk samples were collected $48 \mathrm{~h}$ and $7,15,30$ and 60 days after delivery. The groups did not differ significantly in terms of osmolarity, total proteins and fractions, creamatocrit, calcium, magnesium or potassium throughout the study period. Sodium levels were higher in all samples from mothers of TSGA infants and in samples from mothers of PTAGA infants on the 7th, 15th and 30th days than in milk from the TAGA group. The authors consider the needs of the low birthweight and TAGA infants and that these high sodium levels may be necessary for growth of low birthweight infants.
\end{abstract}

Keywords: Milk, human, physiology. Infant, low birth-weight. Infant nutrition.

\section{Introduction}

Few studics have been conducted to determine the minimum nutrient needs and the ability to tolerate food in small for gestational age term newborns (TSGA) (Bochm et al. ${ }^{6}, 1988$ ). In gencral, studics on the composition of breast milk from mothers of small for gestational age newborns have becin devoled almost exclusively to preterm infants (Amcrican Acad Pcd ${ }^{1}, 1985$ ). Howcver, considcring that TSGA infants make up 5 to $8 \%$ of all newborns and approximatcly 25 to $30 \%$ of very low birthwcight infants (Bochm et al. ${ }^{6}, 1988$ ), it is important to determine the nutritional composition and adequacy of breast milk for this group, specially in devcloping countries.

In view of the difficulty in fixing an ideal wcight gain for this population, it is accepted that the growth rate applicable to premature infants is

* Presented in the 28th Mecting of Latin-American Socicty of Pediatric Investigation, S.Paulo, 1990. Part of a Thesis of A.S.Grumach.

* Department of Pediatrics, School of Medicine of the University of S. Paulo, S. Paulo, SP - Bracil

Reprints: A.S.Grumach, MD - Av. Dr. Encas de Carvalho Aguiar, 647 - 05403-000 - S. Paulo, SP - Brazil FAX: 005511280.9431

Edição subvencionada pela FAPESP. Processo Medicina 93/ 0208-5. identical to that of the weight-height gain occurring during gestation (Amcrican Acad Pcd ${ }^{1}, 1985$ ). However, no specific studies of this type are available for TSGA infants.

The Amcrican Academy of Pediatrics ${ }^{1}$ (1985) recommends the same supply of macronutrients for low birthweight infants regardless of gestational age, with higher protein concentrations and similar fat and carbohydrate concentrations when compared to the diet for TAGA infants.

The composition of brcast milk from mothers of TSGA infants has been investigated in only a fow studics (Garza et al. ${ }^{13}, 1981$; Barros et al. ${ }^{4}$, 1984; Pamblanco cl al. ${ }^{22}$, 1986; Grumach et al. ${ }^{16}$, 1293) and the present study was undertaken to cvaluate the composition of breast milk from mothers of small for gestational age infants delivcred at tcrm and to comparc it to that of milk from mothers of premature infants and adequate for gestational age tcrm infants. These groups of samples were collected until the 60th day of lactation, so the nutritional factors in the same mother could be studicd longitudinally.

\section{Subjects and Methods}

The nursing mothers included in the present study were divided into three groups according to the classification of newborn weight and gestational age: G1, mothers of small for gestational age 
term newborns (TSGA, $\mathrm{n}=16$ ); G2, mothers of preterm appropriate for gestational age newborns (PTAGA, $n=20$ ) and G3, mothers of appropriate for gestational age term newborns (TAGA, $n=30$ ). This procedure was based on the data obtained by Ramos ${ }^{25}, 1986$ in a study conducted at the same hospital and by Battaglia \& Lubchenco ${ }^{5}, 1967$ (Fig. 1). Gestational age was determined taking into account the date of the last menstruation and the criteria of Dubowitz et al. ${ }^{11}, 1970$ and/or Capurro et al. ${ }^{9}, 1978$. Mothers of newborns with gestational age of between 37 and 38 wecks wcre excluded from this study. The gestational age of the TSGA group was 38 to 41.3 weeks (mean 39.2 weeks) and infant birthweight was of from 1,900 to $2,510 \mathrm{~g}$ (mean $2,218 \mathrm{~g}$ ). For the PTAGA group, gestational age ranged from 31.9 to 36.7 wecks (mean 34.6 weeks) and birthweight was of from 1,380 to $2,640 \mathrm{~g}$ (mean $2,065 \mathrm{~g}$ ). For the TAGA group, gestational age was of from 38 to 41.2 wccks (mean 39.1 wccks) and birthwcight was 2,570 to $3,650 \mathrm{~g}$ (mean $3,063 \mathrm{~g}$ )(Fig. 1).

The nursing mothers were in good nutritional condition and used no drugs that might interfere with lactation either during gestation or during the postpartum period. Gestation had heen uneventlul in all cascs. Maternal age, parity, socio-cconomic level (Table) and previous experience with breast
Table. Socio-economic status of mother's delivering TSGA, PTAGA and TAGA neonates.

\begin{tabular}{cccc}
\hline Groups & High & Low & Tolal \\
\hline G1 (TSGA) & 5 & 11 & 16 \\
G2 (PTAGA) & 3 & 17 & 20 \\
G3 (TAGA) & 11 & 19 & 30 \\
\hline Total & 19 & 47 & 66 \\
\hline
\end{tabular}

Goodman test (homogeneity)

$Y^{2}=3.58(\mathrm{~ns}) \quad$ ycrit. $=5.99$

TSGA = mothers of small for gestational age term newborns.

PTAGA = mothers of preterm appropriate for gestational age newborns.

TAGA = mothers of appropriate for gestational age term newborns.

feeding were similar in the three groups (Grumach et al. ${ }^{16}, 1993$ ). All the mothers gave their informed consent to participation in the study and the protocol was presented to an ethics committee of the Hospital.

Colostrum samples were collected during the first 48 hours after delivery and milk samples were collected on the $7 \mathrm{th}, 15 \mathrm{th}, 30 \mathrm{th}$ and $60 \mathrm{th}$ days of lactation. Collection was performed in the morning between breast feedings by manual expression or with the help of a manual breast pump. The
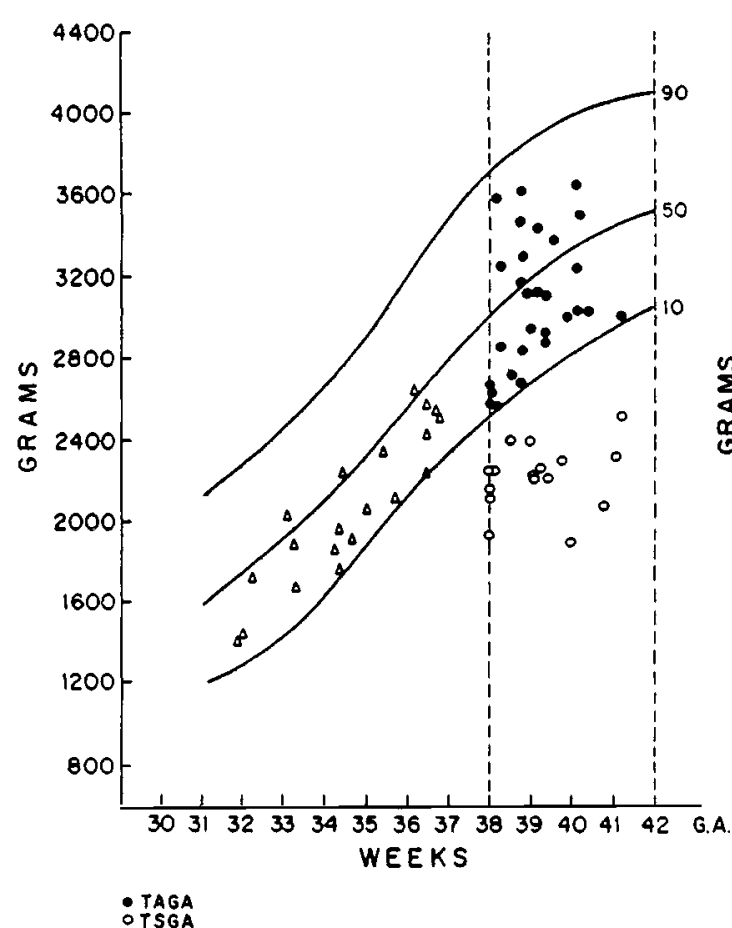

$\triangle$ PTAGA

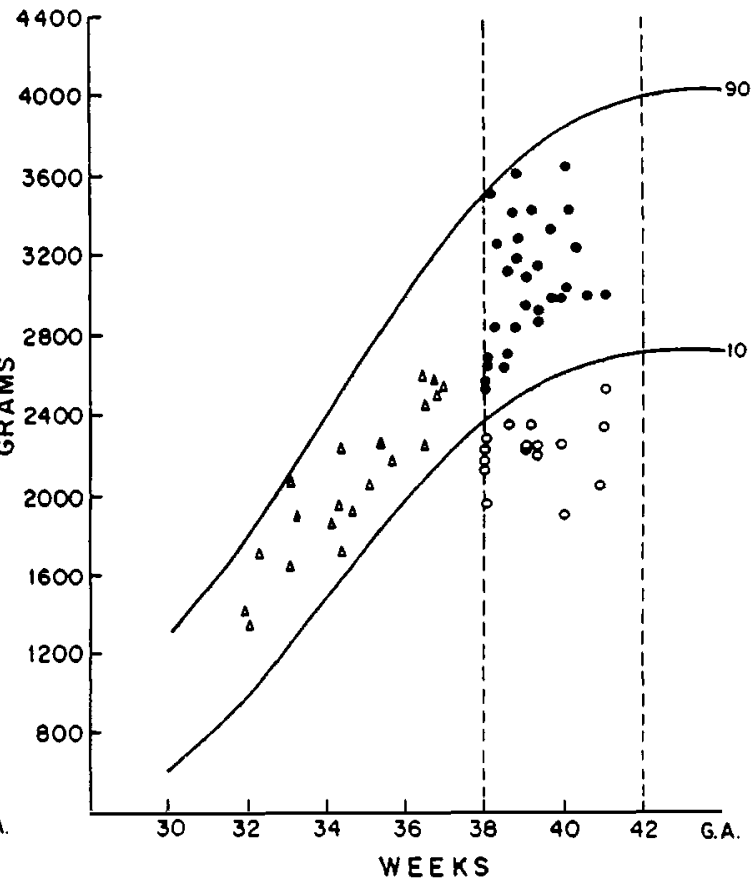

BATTAGLIA \& LUBCHENCO,1967

Figure 1. Weight distribution of neonates in relation to gostational age according to a) Ramos25, 1986 b) Battaglia \& Lubchenco5, 1967. 
samples were divided into aliquots and stored fro$\mathrm{zcn}$ at $-20^{\circ} \mathrm{C}$ for processing and analysis of the material as a whole.

Osmolarity was determined using a model $3 \mathrm{MO}$ Advanced Microosmometer (Advanced Instruments, Massachussets). Fat concentration and calorie content were determined soon after sample collection by obtaining the creamtocrit by the technique of Lucas et al. $.^{20}, 1978$. Total protein concentration was determined by the biuret method. The protcin fractions were separated by elcctrophoresis after defatting the samples (Hibbcrd et al. ${ }^{17}$, 1982). Sodium and potassium levels were determined by flame spectrophotometry, calcium and magnesium levels were determined by atom absortion spectrophotometry (Nóbrega et al. $\left.{ }^{21}, 1985\right)$.

Data were analysed statistically using nonparametric tests:

a) Mann-Whitncy test to compare TAGA and TSGA groups and to compare preterm and tcrm newborns within the AGA group (Dorea ct al. $\left.{ }^{10}, 1982\right)$; b) Fricdman analysis of variance to compare the values obtained for each group separatcly at each collection time (Dorea et al. $\left.{ }^{10}, 1982\right)$. Homogencily lest of Goodman (Thomas ct al. ${ }^{28}, 1986$ ) was used to analyse the presence or not of differences between the three groups (socio-economic levels, parity, maternal age).

\section{Results}

Sample osmolarity up to the 60 th day was equivalent for all three groups (approximately 290 $\mathrm{mOsm} / 1$ ), with stable values being detected throughout the collection period (Fig. 2). Mothers of TSGA newboms had a smaller percentage of fat in colostrum and higher percentage in the 30 h day milk in relation to the control $(\mathrm{p}<0.05$ ) (Fig. 3). Milk from mothers of premature newborns has creamtocrit similar to the control group. The values detected varied widely for all three groups, with a fall in creamtocrit from 48 hours up to the 30 th day of collection for $\mathrm{G} 1$ ( $\mathrm{p}<0.05)$.

Total protcin concentrations were similar for all three groups, with significanthy higher values during the first 48 hours in relation to the $60 \mathrm{th}$ day for G3 ( $p<0.05)$ (Fig.4). Through the study of protein fractions, there was a predominance of beta and gamma fractions in colostrum, with small variations throughout the collection period for all threc groups. Albumin concentration and

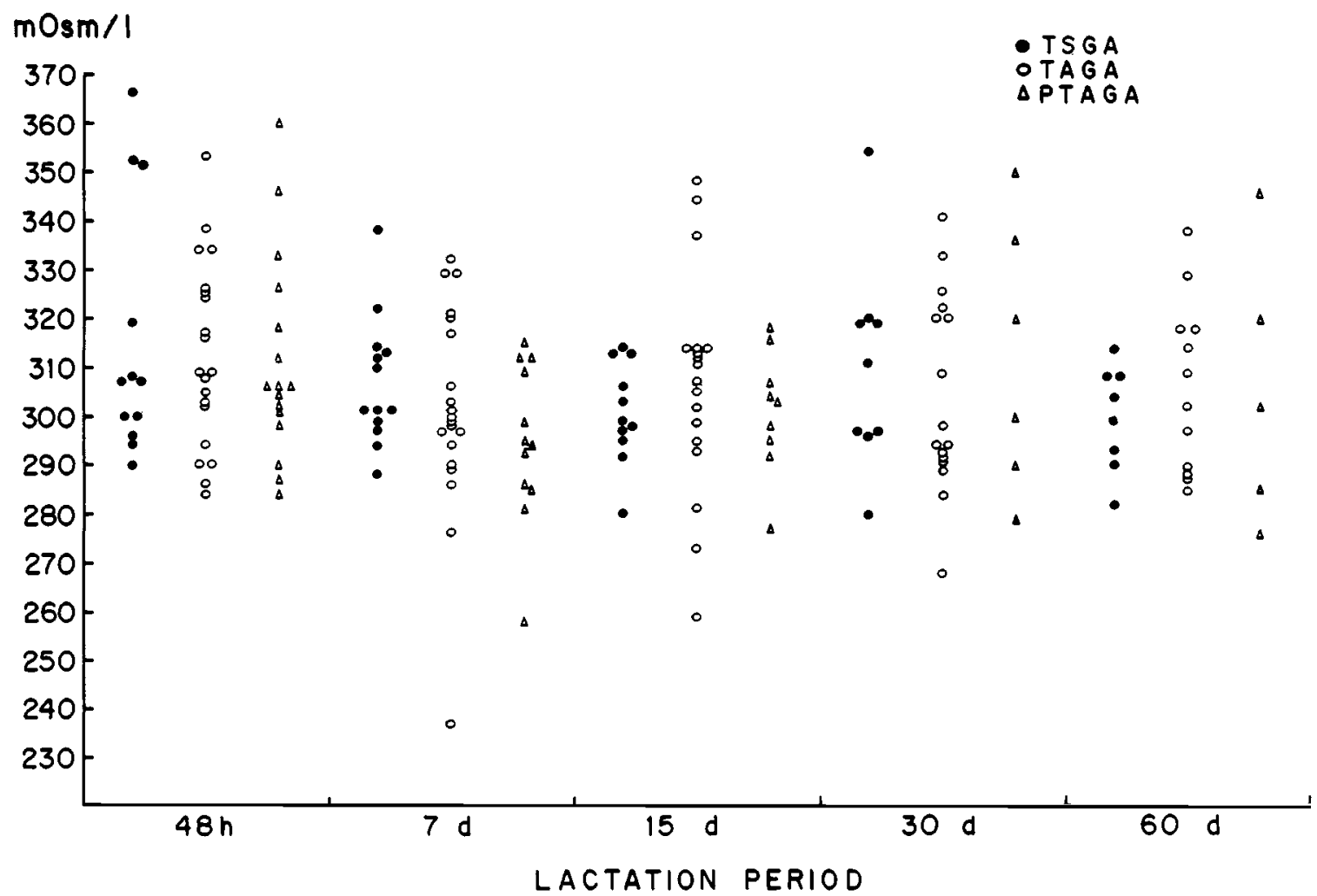

Figure 2. Osmolarity of colostrum and milk (up to the 60th day of lactation) from mothers of TSGA infants, of PTAGA infants and of TAGA infants (mOsm/l). 


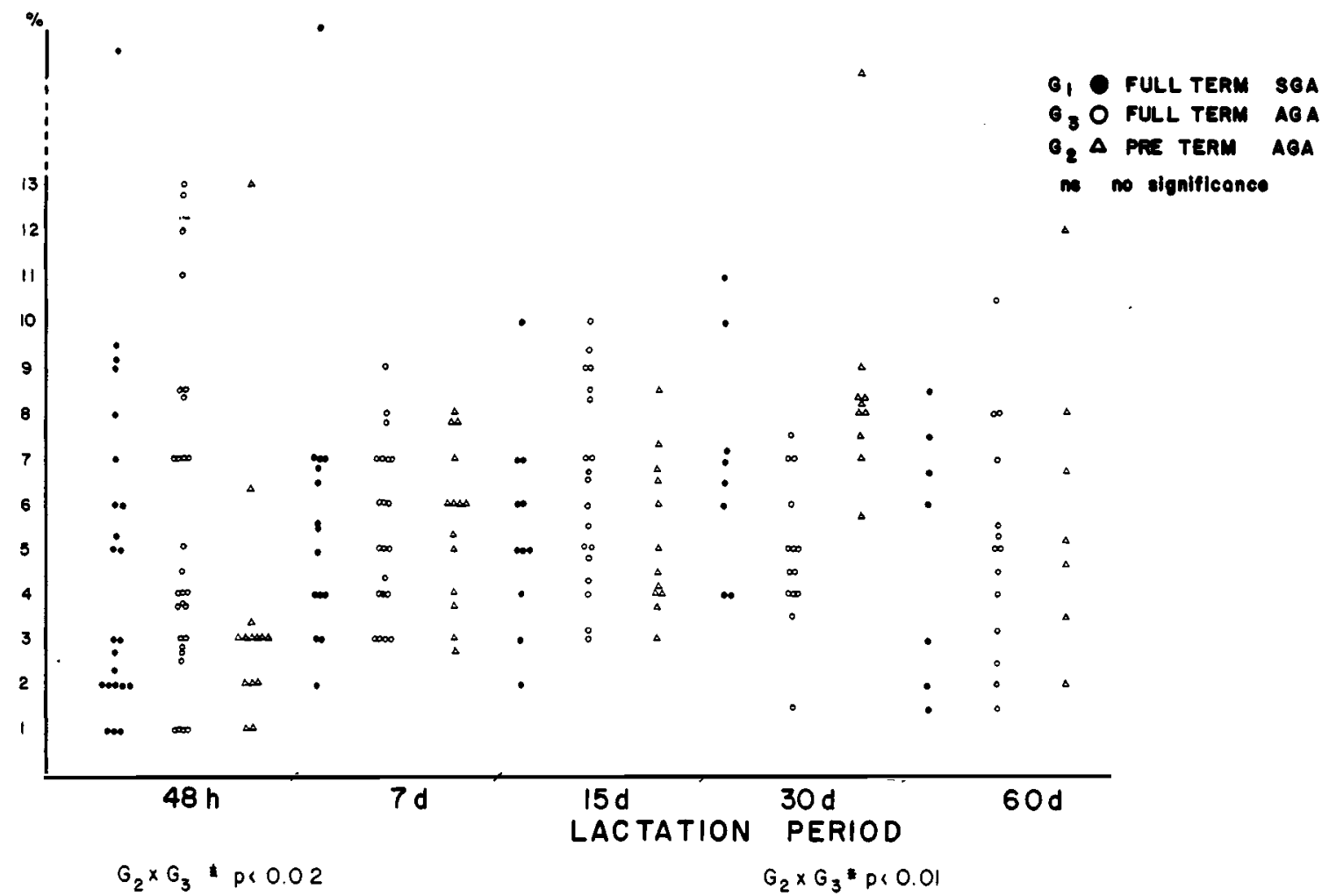

Figure 3. Creamatocrit in colostrum and milk (up to the 60 th day of lactation) from mothers delivering TSGA, PTAGA and TAGA infants $(\%)$.

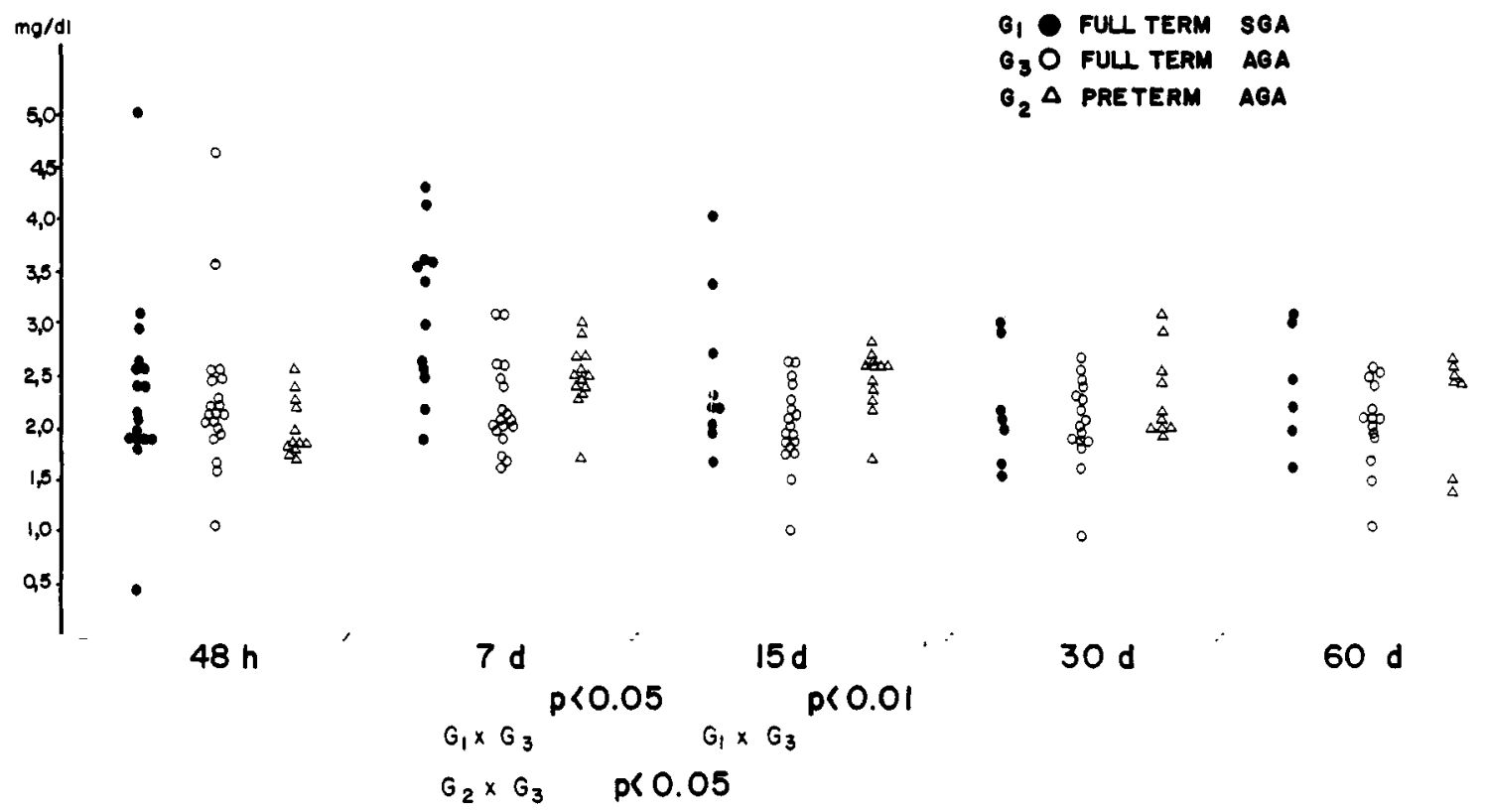

Figure 4. Total protein concentration in colostrum and milk (up to the 60 th day of lactation) mothers delivering TSGA, PTAGA and TAGA infants $(g / l)$. 


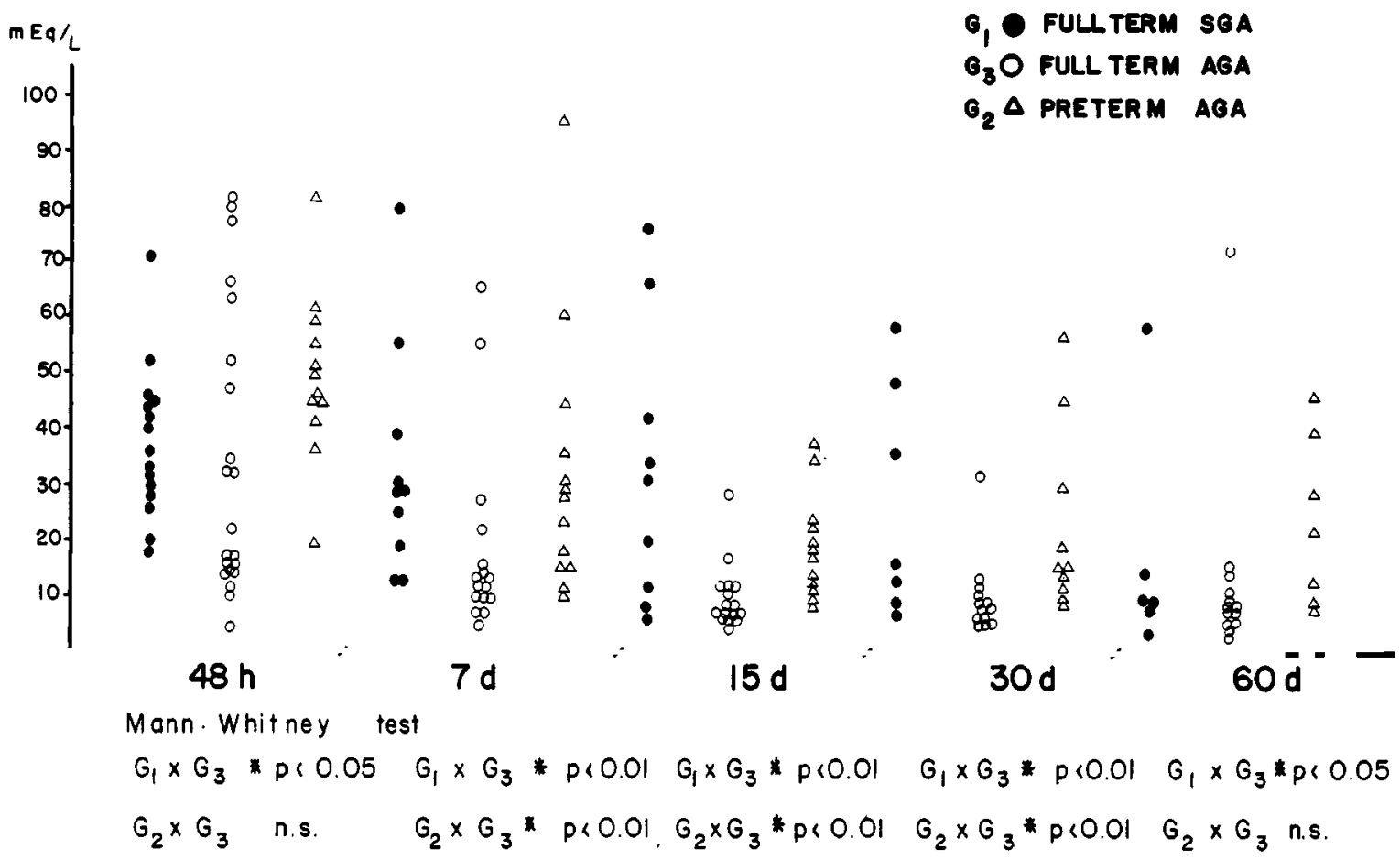

Figure 5. Sodium levels in colostrum and milk (up to the 60 th day of lactation) from mothers delivering TSGA, PTAGA and TAGA infants (mEq').

alfa 2 fraction wcre significantly less in the TSGA group in relation to the TAGA group in the 60 th day milk $(p<0.05)$. Alfa 2 fraction was also less in the TSGA in the 30th day milk $(p<0.05)$. There were no other significant differences between the groups in the protein fractions cvaluation.

Sodium levels were elevated in milk from mothers of TSGA infants throughout the collection period and in milk from mothers of PTAGA infants on the 7 th, 15 th and $30 \mathrm{th}$ days of lactation when compared to the TAGA group $(p<0.01)$ (Eig.5). Potassium and calcium concentrations did not differ among groups or collection times. Magnesium levels were significantly higher in the $7 \mathrm{th}$ $(p<0.05)$ and 15 th day $(p<0.01)$ of lactation in the $\mathrm{G} 1$ group as observed on the 7th day for the G2 group $(p<0.05)$.

\section{Discussion}

Doubts persist as to the adcquacy of breast milk composition in terms of mecting metabolic and immunological needs of low birthweight infants. In addition to this lack of information on the com. position of brcast milk, brcast-fecding of low birthwcight infants tends to be discouraged because of the prolonged hospitalization of these ba- bics, complications that prevent oral feeding and lack of physical contact with the mother. Although these factors are less frequent among TSGA newborns, the composition of their mothers' milk is still little known, a matter that motivated the present study.

In order to reduce the number of factors that might interfere with sample quality, nursing mothers with any type of chronic disease or who were using drugs were excluded, and good maternal nutritional status was a requirement for admission to the study. These are the reasons which led to a reduction in the total number of mothers and colostrum and milk samples in the groups studied, as pointed out earlicr. Ramos ${ }^{25}$ and Battaglia \& Lubchenco's classification of newborn's weight and gestational age ${ }^{5}$ was also taken into consideration. This procedure was adopted in order to compare a local classification with an Internationally accepted pattern.

Osmolarity was analysed up to the 60 th day of brcast-fceding and it was found to be stable and close to $290 \mathrm{mOsm} / 1$ in all three of the groups studied. No specific studies on the milk of mothers of TSGA infants are available, but similar valucs have becn previously detected in the milk of mothers of premature infants (Hibberd et al. 17,1982 ).

The creamatocrit technique was used to detcrmine fat concentration in the samples, since this 
is an easily exccuted, low cost method requiring small volumes, thus permilting a rapid evaluation of the caloric content of breast milk (Lucas et al. ${ }^{20}, 1978$ ).

Despite the care taken during collection, creamatocrit values varied widely as has been described before (Nóbrega et al. ${ }^{21}, 1985$ ). Except for the milk samples obtained during the first 48 hours from mothers of TSGA infants, no differences were detected between the low birthweight and the TAGA groups, as has also becn observed by othcrs (Barros \& Carnciro-Sampaio ${ }^{4}, 1984$ ). Longitudinal creamatocrit analysis showed higher levels in 30-day milk than in colostrum of mothers of the TSGA group. Human milk variation due to differences between the right and left breast at collecLion or to the presence of final residue of previous fecding, affecting fat concentration has been obscrved (Dorca et al. ${ }^{10}, 1982$ Thomas et al. ${ }^{28}$, 1986). Lucas et al..$^{20}$ (1978) have proposed a formula for the conversion of creamatocrit to fat concentration and caloric content of the samples. Both fat and total calorie concentrations obtained in the present study were similar to those reported in the literature for the milk of the mothers of premature infants and were sufficient to satisfy minimum requirements, in the light of the data previously published (Ferris et al. ${ }^{12}, 1988$; Butte ${ }^{8}, 1988$ ). There are no reports on the ideal fat and calorie levels for TSGA infants.

The ideal protcin concentration in breast milk for low birthweight infants is still a controversial subject (Reynolds's6, 1985, Ronnholm et al. ${ }^{27}$, 1986). Weight gain has been the main parameter for the cvaluation of protcin supply, but this form of cvaluation does not take into account protcin quality (Räiha ct al. ${ }^{24}, 1976$ ).

The protein levels detected in the milk of premature and TSGA infants' mothers were similar to those in the milk of TAGA infants' mothers, with a drop in levels during lactation, as also rcported by others (Anderson ${ }^{2}, 1983$, Butte et al. ${ }^{7}$, 1984). However, there are reports that milk of mothers who delivered premature infants has a greater protein concentration that satisfics the infanl's necds (Pamblanco ct al. ${ }^{22}, 1986$, Lemons ct al. ${ }^{19}, 1986$ ), though no conclusive data are available for TSGA infants.

When the weight and height gains of the newborns studied here were monitored up to the 60th day of collection, no impaired growth was obscrved in exclusively breast-fed premature or TSGA infants, both groups gaining 20-30 g per day on avcrage.

Albumin concentration was constant in all samples throughout the collection period, with similar levels in the three groups except for the fall ob- served on the 60uh day in milk from mothers of TSGA infants. There was a predominance of beta and gamma fractions, certainly reflecting the high IgA concentrations, with a fall in their levels occurring as early as on the 7th day of lactation (Barros \& Carneiro-Sampaio ${ }^{4}$, 1984, Pamblanco et al. ${ }^{22}$, 1986).

Sodium, chloride and potassium are the main electrolytes present in body fluids. Under basal conditions, urinary sodium excretion is higher in preterm than in term infants. An inverse relationship between urinary sodium excretion and gestational age has been reported (Aperia et al. ${ }^{3}, 1985$ ). Thus, premature infants require a greater sodium supply to avoid hyponatremia and small for gestational age term infants are supposed to have a more mature renal function than preterm infants (Aperia et al. ${ }^{3}, 1985$ ).

The milk from TSGA infants' mothers had clevated sodium levels throughout the collection period in the present study, presenting about twice the value found in milk from mothers of TAGA (G3) from the 7th up to the 60th day of lactation. Sodium was also elevated on the $7 \mathrm{th}$, 15 th and 30th days in milk from mothers of PTAGA (G2) but these high levels did not result in altcration of osmolarily in both low birthweight groups $(G 1, G 2)$. These results are in agrecment with values oblained by Barros \& Carneiro-Sampaio ${ }^{4}$ (1984) in colostrum and in $7 \mathrm{ht}$ day milk. The high sodium levels may he necessary to the premature infant as has been mentioned above, but this eletrolyte was also found to be high in breast milk for TSGA infants, despite the longer period of gestation.

Potassium levels were constant throughout the collection period and equivalent in all groups giving support to the idea that the greater sodium concentration in the milk of TSGA infants' mothers is not due to a smaller potassium value, as proposed by other investigators (Barros \& CamciroSampaio $^{4}, 1984$; Gross et al. $\left.{ }^{15}, 1980\right)$.

Calcium, magnesium and phosphorus arc essential minerals for tissue structure and function (Koo \& Tsang ${ }^{18}$, 1988). The supply of calcium and phosphorus in the milk from mothers of low birth-weight preterm infants has been considered to be insufficicnt (Pcrcira \& Barbosa ${ }^{23}, 1986$; Goshi $\left.{ }^{14}, 1989\right)$. Comparative analysis of the threc groups did not show significant differences up to the 60th day of lactation, as also observed by others (Garza et al. ${ }^{13}$, 1981; Butte et al. ${ }^{8}, 1984$ ). The calcium levels detected during this study do not permit the conclusion that they are insufficient for low birthweight infants.

Significant higher magnesium levels were observed in low birthweight groups in the 7 th 
(G1\&G2) and 15th (G1) day of lactation, as also reported by Garza et al. ${ }^{13}$ (1981).

On the basis of the nutritional factors evaluated in the present study, it was found that, in gencral, protein and fat levels arc similar in milk of low birthweight infants when compared to appropriate for gestational age term newborns. With regard to sodium values, it might be supposed that a greater supply leads to greater fluid retention, which is needed for growth, while at the same time the replacement of urinary sodium loss is necessary for premature newborns (Aperia et al. ${ }^{3}, 1985$ ). Nutritional balance studies should be performed in order to support this hypothesis.

The possibility that concentration occurs in the breast milk from mothers of low birthweight infants as a consequence of a lesser volume can not be accepted on since the other parameters studied had not followed sodium values (Gross et al. ${ }^{15}$, 1980). Maintenance of high sodium levels during all period of collection for TSGA group (G1), even after their mothers produce more milk, have also been observed.

It should be cmphasized that this study was the first conducted to evaluate nutritional factors in the milk of small for date term infants' mothers over a period of 60 days of lactation. The results show some differences in breast milk of low birthweight infants although some doubts still persist as to the adequacy of the calcium and magnesium content, which could only be fully clarified in prospective clinical studies, including nutritional balances.

\section{Conclusions}

The nutritional composition of breast milk from mothers delivering small for gestational age infants, taking into consideration total protcins and fractions, crcamatocrit, calcium, magncsium, potassium and osmolarity, did not differ from that from mohers delivering term adequate for gestational age newborns. Sodium levels in colostrum and milk up to the 60th day after delivery were higher for mothers delivering small for gestational age term infants. Nutritional balances should be devcloped so that further conclusions regarding these findings might be arrived at.

\section{Acknowledgements}

We wish to thank the nursing mothers whose collaboration permitted us to conduct the present study. We are grateful to Dr. Elias Sevciovic and Mrs. Elictra Greene for revising the text, to Profs. Ncil Fcrrcira and Yara Juliano for statistical assis- tance, and to the Brazilian National Research Council ( $\mathrm{CNPq})$, Nestle Nutrition and the British Council for financial support.

GRUMACH, A.S. et al. Fatores nutricionais no leite de mães brasileiras de recém-nascidos de baixo peso para idade gestacional. Rev. Saúde Pública, 27: 455-62, 1993. A composição do leite de mãcs brasileiras de lactentes de baixo peso e sua adequação como fonte de nutrientes para este grupo ainda não foi totalmente elucidada. Um total de 209 amostras de leite de 66 nutrizes foram analisadas. As mães foram divididas em três grupos: G1, mães de recém-nascidos(RN) a termo, com baixo peso (TSGA, $n=16$ ); G2, mães de $R N$ pré-termo, com peso adequado (PTAGA, $n=20$ ); $G 3$, mães de $R N$ a termo e peso adequado (TAGA, $n=30$ ). Os seguintes fatores foram analisados: osmolaridade, proteínas totais e frações, crematócrito, sódio, potássio, cálcio e magnésio. As amostras foram coletadas $48 \mathrm{~h}$, no $7^{\circ}, 15^{\circ}$, $30^{\circ}$ e $60^{\circ}$ dias após o parto. Os grupos não diferiram em termos de osmolaridade, proteínas totais e frações, crematócrito, cálcio, magnésio ou potássio durante o estudo. Os níveis de sódio foram maiores em todas as amostras de mães de TSGA e em mães de PTAGA no $7^{\circ}, 15^{\circ}$ e $30^{\circ}$ dias em relação a mães de TAGA. Foram consideradas as necessidades dos lactentes de baixo peso e TAGA, e estes níveis de sódio podem scr necessários para o crescimento dos RN de baixo peso.

Descritores: Leite humano, fisiologia. Baixo peso ao nascer. Nutrição infantil.

\section{References}

1. AMERICAN ACADEMY OF PEDIATRICS. Nutritional needs of low birhweight infants. Pediatrics, 75:976-86, 1985.

2. ANDERSON, D.M. Length of gestation and nutritional composition of human milk. Am. J. Clin. Nutr., 37:\$10-4, 1983.

3. APERIS, A.; IIERIN, P.; ZETTERSTROM, R. Sodium chloride and potassium needs in very low birthweight infants. In: Tsang, R.C. ed. Vitamin and inineral requirements in preterm infants. New York, Marcel Dekker, 1985 . v. 3 p. 137.51.

4. BARROS, M.D. \& CARNELRO-SAMPAIO, M.M.S. Milk Composition of low binhweigth infants' mothers. Acta Paediatr. Scand., 73:693-4, 1984.

5. BATTAGLIA, F.C. \& LUBCIIENCO, L.O. A practical classification of newbon infants by wcight and gestational age. J. Pediatr., 71:159-63, 1967.

6. BOEIMM, G.; SENGER, II,; BRAUN, W.; BEYERESS, K.; RÄIHA, N.C.R. Metabolic differences between AGA and SGA infants of very low birhweight. I. Relationship to intrauterine growth retardation. Acta Paediatr. Scand., 77:19-23, 1988.

7. BUTTE, N.F. Energy requirements during infancy. In: Tsang, R.C.; Nichols, B.L., eds. Nutrition during infancy. Philadelphia, Hanley \& Belfus, 1988. p. 86-99.

8. BUTTE, N.F.;GARZA, C.; JOIINSON, C.A.; OBRIAN, S.E.; NICIIOLS, B.L. Longitudinal changes in milk composition of mothers delivering preterm and term in. fants. Early Ilum. Dev., 9:153-62, 1984. 
9. CAPURRO, H.; KONICHEZKY, S.; FONSECA, D.; CADEYRO-BARCIA, R. A simplified method dor diagnosis of gestational age in the newbom infant, J. Pediatr., 93:120-2, 1978.

10. DOREA, J.G.; HORNER, M.R.; BEZERRA, V.L.V.; CAMPANETE, M.L. Variation in major constituents of fore and hindmilk of brazilian women. J. Trop. Pediatr., 28:303-5, 1982.

11. DUBOWITZ, L.M.S.; DUBOWTTZ, V.; GOLDBERG, C. Clinical assessment of gestational age in the newbom infant. J. Pediatr., 77:1-10, 1970.

12. FERRIS, A.M.; DOTTS, M.A.; CLARK, R.M.;EZRIN, M.; JENTSEN, R.G. Macronutrients in human milk at 2,12 and 16 weeks post partum. J. Am. Diet. Assoc., 88:6947, 1988.

13. GARZA, C.; JOIINSON, C.A.; BUTTLE, N.F.; SMTTH, O.; NICIIOLS, B.L. Longitudinal changes in milk composition of mothers delivering preterm and small for gestational age infants. Pediatr. Res., 15:532, 1981.

14. GOSHI, L.H. Metabolismo do cálcio e do fósforo através de técnica de balanço no recém-nascido de muito baixo peso em alcitamento matemo. S.Paulo, 1989. [Master's thesis University of S.Paulo]

15. GROSS, S.J.; DAVID, R.J.; BAUMAN, L.; TOMARELLI, R.M.Nutritional composition of milk produced by mothers delivering preterm. J. Pediatr., 96:641-4, 1980.

16. GRUMACH, A.S.; CARMONA, R.C.; LAZAROTTI, D.; RIBEIR0, M.A.; ROZANTRAUB, R.B.; RACZ, M.L.; WELBERG, $\Lambda$; CARNEIRO-SAMPAIO, M.M.S. Immunological factors in milk from Brazilian mothers delivering small-for-date neonates. Acta Paediatr. Scand., 82: $284-90,1993$.

17. IIIBBERD, C.M.; BROOKE, O.G.; CARTER, N.D.; IIAUG, M; HARZER, G. Variation in the composition of breast milk during the first 5 weeks of lactation: implications for the feeding of preterm infants. Arch. Dis. Child., 57:658-62, 1982.

18. KOO, W.W.K.; TSANG, R.C. Calcium, magnesium and phosphorus. In: Tsang, R.C. \& Nichols, B.L., eds. Nuirition during infancy. Philadelphia, Ilanley \& Belfus, 1988. p. 175-89.
19. LEMONS, P.; STUART, M.; LEMONS, J.A. Breastfeeding the premature infant. Clin. Perinatol., 13:11. 22, 1986.

20. LUCAS, A.; GIBBS, J.A.H.; LYSTER, R.L.J; BAUM, J.D. Creamatocrit: simple clinical technique for estimating fat concentration and energy values of human milk. $B r$. Med. J., 1:1018-20, 1978.

21. NÓBREGA, F. J.; AMANCIO, O.M.S.; MARN, R.; KOP. PEL, S.; SINGH, M.; VASCONCELOS, M. Leite de nutrizes de alto e baixo nível econômico, eutróficas e desnutridas. I. Gorduras totais, valor calórico total e estudo ponderal dos lactentes. J. Pediatr., 59:174-80, 1985.

22. PAMBLANCO, M.; TEN, A.; COMIN, J. Proteins in preterm and term milk from mothers delivering appropriate and small for gestational age infants. Early Hum. Dev., 14:267-72, 1986.

23. PEREIRA, G.R. \& BARBOSA, N.M.M. Controvérsias em nutrição neonatal. Pediatr. Clin. North Am., 33:69-94, 1986.

24. RÄIHA, N.C.R.; HEINONEN, K.; RASSIN, D.K.; GAULL, G.E. Milk protein quantity and quality in low birthweight infants: I. Metabolic responses and effects on growth. Pediatrics, 57:659-74, 1976.

25. RAMOS, J.L.A. Características do crescimento fetal. In: Ramos, J. L. A. \& Leone, C.R., eds. 0 récem-nascido de bairo peso. São Paulo, Sarvier, 1986. p. 5-16.

26. REYNOLDS, J.W. Nutrition of the low birthweigth infant. In: Walker, W.A. \& Walkins, J.B. Nutrition in pediat. rics: basic science and clinical application. Boston, Little Brown, 1985. p. 649-62.

27. ROBERTON, D.M.; FORREST, P.J.; FRANGOULIS, E.; JONES, C.L.; MERMELSTEINS, N. Early induction of secretory immunity in infancy: specific antibody in neonatal breast milk. Arch. Dis. Child, 61: 489-94, 1986.

28. THOMAS, M.R.; CIIAN, G.M.; BOOK, L.S. Comparison of macronutrient concentration of pretern human milk between two milk expression techniques and two techniques for quantitation of energy. J. Pediatr. Gastroen. terol. Nutr., 5: 597-601, 1986.

Recebido para publicação em 28.5 .1993

Reapresentado em 2.9.1993

Aprovado para publicação em 1.10.1993 